\title{
INTRODUCTION to the Revised Edition
}

In Memory of Leo Lowenthal

It is safe to say that Walter Benjamin: An Aesthetic of Redemption was written in the afterglow of the political and cultural upheavals associated with the New Left. It is also of sorts a Jugendschrift: my first attempt to come to grips with the emancipatory promise of that "warm current" (E. Bloch) of central European, philosophical Marxism that blossomed during the interwar years. ${ }^{1}$

It comes, therefore, as no small source of satisfaction that the work has remained serviceable for scholars and students in their efforts to come to terms with Benjamin's fascinating, yet inordinately demanding, oeuvre. At the time of composition, I thought it superfluous to proceed mimetically vis-à-vis Benjamin's prose-to be sure, always a great temptation-in order to produce a "virtuoso" study of a writer who was himself a virtuoso. Instead, I felt strongly that my goal would be accomplished were I to engage in a critical reconstruction of the broad outlines of Benjamin's circuitous and hermetic intellectual path. Convinced that more specialized, scholarly investigations of his work would soon follow (they have in great numbers), I felt that an English-speaking public would be best served by a book that focused on the central themes of Benjamin's work: from his Kabbalistically derived philosophy of history to his later self-understanding of a historical materialist. I am extremely grateful to my editor at the University of California Press, Edward Dimendberg, for his consistent support and enthusiasm for a new edition of the present book. I would also like to acknowledge the generous financial support of the German Marshall Fund of the U.S.

I dedicate this edition to the memory of the great Frankfurt School sociologist of literature, Leo Lowenthal (1900-1993). In ad- 
dition to having been an associate of Benjamin's at the Institute for Social Research in the late 1930s, Leo put up a spirited defense of Benjamin's ill-fated Baudelaire essay, "Paris of the Second Empire in Baudelaire." Our friendship began in the late 1970s in Berkeley as my own labors on Benjamin had just begun. As a representative of that unique generation of utopia-inspired, central European Jewish thinkers that came of age circa World War I, Leo was much more than an intellectual model; he was the living embodiment of an entire theoretical tradition. I consider it a privilege to have known him. He was a unique spirit in the annals of critical thought. His intellectual tenacity, which he maintained until the end, will be sorely missed by many.

One of the key concepts in the thought of the later Benjamin is that of Aktualität or (cumbersomely translated into English) "contemporary relevance." The first collection of essays devoted to an understanding of his work, Zur Aktualität Walter Benjamins, highlighted precisely this dimension of his thought. ${ }^{2}$ Like the truth content of the work of art, on which Benjamin reflects in his essay on Goethe's Elective Affinities, the relevance of his thought is not something that is simply vorhanden or immediately available. In Benjamin's case, too, "truth content" comes only by way of an outer veneer, a "material content" (Sachgehalt). Here, material content refers to the fact that his oeuvre was conceived under a very precise set of historical circumstances: the tumultuous years spanning the outbreak of two catastrophic world wars; a period in whose aftermath many of the self-evidences of European civilization were seemingly left hanging by a thread; an era dominated by the political extremes of communism and fascism, in which the survival of democracy seemed at best remote.

Is it, then, any wonder that, from Benjamin's very earliest intellectual stirrings, eschatological motifs occupied a position of prominence in his thought? Indeed, a profound spirit of apocalyptical imminence pervades both his youthful and mature writings. 
Ours, conversely, is an epoch that has seen too much of apocalypse-world war, death camps, the Soviet Gulag, Hiroshima, Vietnam. It is an age that is understandably weary of fanciful, eschatological political claims. It is an era that has become enlightened-or so one would like to believe-about the folly and zeal of political theology: the notion that the kingdom of ends might be realized on earth via secular political means. We have become properly mistrustful of redemptory political paradigms. ${ }^{3}$ In Kantian terms, the excesses of political messianism have taught us to be wary of all attempts to fuse the noumenal and phenomenal realms. Indeed, the idea that what is foremost at issue in the domain of secular political life are considerations of justice or fairness, and that questions of salvation must be relegated to the private sphere as the province of individual conscience, seems to be one of the quintessential legacies of political modernity. ${ }^{4}$

As Irving Wohlfarth has pointed out: "To apply Benjaminian categories to the present without also trying to rethink them in the light of intervening history is . . . not merely to remain trapped within the coordinates of his thought, but to arrest the recasting process that it sought to initiate." ${ }^{5}$ His caveat is directed to those who succumb to an ever-present danger of Benjamin scholarship: the danger of overidentification. For those who seek to follow in Benjamin's footsteps run the risk of becoming mesmerized by the aura of his life and thought. Before they can be appropriated, his ideas must be subjected to an alienation-effect - their spell must be broken, they must be deauraticized. To this end, they must be unflinchingly brought into contact with other intellectual traditions, as well as new historical circumstances. Only through such a confrontation might they prove their worth. The greatest disservice one could do to his theoretical initiatives would be to accord them the status of received wisdom, to assimilate them uncritically or wholesale. His mode of thinking, both alluring and elusive, invites commentary and exegesis, which must not be confused with adulation.

For all of these reasons, the attempt to appropriate Benjamin's intellectual legacy under dramatically different historical circumstances is a far from simple matter. To begin with, one would have to do justice to the fact that his interpretation of history remains inalienably wedded to a problematic of unremitting cataclysm and catastrophe, as the following observations indicate: 
That things have gone this far is the catastrophe. Catastrophe is not what threatens to occur at any given moment but what is given at any given moment. 6

If the abolition of the bourgeoisie is not completed by an almost calculable moment in economic and technical development (a moment signaled by inflation and poison-gas warfare), all is lost. Before the spark reaches the dynamite, the lighted fuse must be cut. ${ }^{7}$

Counterpart to [Auguste] Blanqui's worldview; the universe is a locus of perpetual catastrophe. ${ }^{8}$

And in his legendary discussion of the "angel of history"-perhaps the defining image of his entire work-Benjamin affirms that, "Where we perceive a chain of events [the angel] sees one single catastrophe which keeps piling wreckage upon wreckage and hurls it in front of his feet." $\mathrm{He}$ identifies the storm responsible for this catastrophe simply with "progress." Hence, for Benjamin, it is the responsibility of the critic to "brush history against the grain." For if left to itself, the immanent course of history will never produce redemption. That is why the historical materialist must "blast open the continuum of history." Only in this way can he or she activate its veiled redemptory potentials, which Benjamin (in a clear allusion to the mystical nunc stans) associates with Jetztzeit or the "time of the now."

To be sure, there are certain strains of postmodernist thought which approximate Benjamin's bleak understanding of history as a Verfallsgeschichte or a "history of decline"-e.g., Foucault's cheerless image of a "carceral society" or Baudrillard's concept of the omnipresence of "simulacra." But often they purvey inordinately dispirited images of contemporary society which, for their part, are wholly denuded of the utopian sensibility that infuses Benjamin's work. ${ }^{10}$

For Benjamin at least tried to uphold a vision of utopian possibility that resides beyond the fallen and desolate landscape of the historical present. Postmodernism, conversely, by fetishizing the notion of posthistoire, conveys a sense that all attempts to actualize elements of the past for the sake of an emancipated future are a priori consigned to failure. For example, the concept of "historicism," proper to postmodern architectural theory, intends less a meaningful actualization of the past than an avowedly random historical pillag- 
ing of it. In Benjaminian terms, the past is less cited as a now-time ("a sign of messianic cessation of happening") 11 than as a purely ornamental adornment. The end result in most cases is a reaestheticized version of the modern.

With postmodernism, moreover, the very concept of emancipation is relegated to the dustbin of unserviceable metaphysical concepts. But thereby, too, the crucial philosophical distinction between essence and appearance is abandoned. Once these terms are relinquished, one risks surrendering the capacity to make significant conceptual distinctions. For postmodernism, as was already true in Nietzsche, appearance is all there is. For Benjamin, conversely, appearance is the realm of phantasmagoria-it bespeaks the spell of commodity fetishism, that degenerate utopia of perpetual consumption that must be demystified and surmounted. But then, since Benjamin never made a secret of his predilection for metaphysical, even theological modes of thought, the attempt to reconcile his thinking with the antimetaphysical stance of postmodernism has always been somewhat strained. ${ }^{12}$

Since Benjamin was engaged in some of the pivotal aesthetic controversies of our time, he is at present a logical candidate for inclusion in the burgeoning cultural studies canon. Yet, it may be that the attempt to understand contemporary culture in accordance with Benjamin's eschatological theory of history-which is predicated on the notion of the present as a perpetual "state of emergency"obfuscates more than it clarifies. For while in 1940, following $\mathrm{Na}$ zism's initial successes, Benjamin could with some plausibility characterize "the 'state of emergency' in which we live [as] not the exception but the rule," 13 this claim can at best have metaphorical meaning when applied to the historical present. ${ }^{14}$ Conversely, if today the "state of emergency" is understood literally rather than metaphorically, one risks systematically underestimating the existing possibilities for political intervention and criticism. The result can be-and often is - a paralysis and marginalization of left-wing oppositional practice. A position that proceeds from the assumption that the capitalist state is inherently fascist or totalitarian is predestined to inefficacy. Moreover, it commits the mistake of generalizing such concepts to the point where they are rendered both trivial and meaningless-precisely the opposite effect that an understanding of totalitarian political forms should strive to promote. 
If Benjamin's eschatological temperament places him at odds with the modest political aims of contemporary democratic practice, it nevertheless serves as an important corrective to the postmodernist embrace of posthistoire. ${ }^{15}$ Postmodernism has not only abandoned "metanarratives." In its anti-Hegelianism, it has also rejected one of the basic premises of dialectical thought: the idea that, despite its apparent indigence, the contemporary social situation might yield something qualitatively better. The desire to perceive hope beyond despair - a central feature of Benjamin's redemptory approach to cultural history-is a sentiment that is alien to the disillusioned mood of postmodernity. For the very concept of posthistoire suggests that the Enlightenment project of reconciling history and reason-a project that still finds a prominent echo in Hegel's thought-is illusory if not dystopian. Yet not even Benjamin, for all his reservations about "progress," was so antagonistically disposed toward Enlightenment ideals. He went so far as to provide himself with the following methodological watchword for the Passagenwerk, one that would have been worthy of Kant or Condorcet:

To make arable fields where previously only madness grew. Going forward with the sharp axe of reason, refusing to look left or right, in order not to succumb to the horror that beckons from the depths of the primeval forest. The entire ground must be made arable by reason in order to be purified from the jungle of delusion and myth. That is what I would like to accomplish for the nineteenth century. ${ }^{16}$

Because Benjamin's intellectual sensibility was profoundly shaped by the experience of the interwar years, it was conditioned by an acute sense of historical collapse that parallels Nietzsche's no less apocalyptical diagnosis of "European nihilism" in The Will to Power. "What does nihilism mean?" inquires Nietzsche. "That the highest values devaluate themselves. The aim is lacking; 'why?' finds no answer." 17 And with this summary pronouncement on the utter untenability of inherited European values, Nietzsche initiated a line of radical Kulturkritik that would often prove as influential for those on the left as on the right. ${ }^{18}$ 
It is far from surprising, therefore, that in the notes and drafts to the Passagenwerk, Benjamin betrays a fascination for Nietzsche's doctrine of eternal recurrence. It was an idea he thought he could make serviceable for his critique of nineteenth-century historical consciousness: in it he found an appropriate antidote to the bourgeois belief in progress in an epoch-the era of imperialism or high capitalism - where there was no longer anything "progressive" about the rule of this class. Moreover, it was an idea that seemed to accord with Benjamin's own conception of the nineteenth century as the site of a mythic proliferation of commodity fetishism-a phantasmagoria. Like Benjamin, Nietzsche was a staunch critic of historicism. Yet, for this reason (and due to the archaicizing predilections of his thought), he glorified the mythological implications of eternal recurrence. Conversely, although Benjamin believed that the concept expressed a fundamental truth about the nature of bourgeois society-as a society that, owing to the inescapable compulsions of the commodity form, remained essentially indebted to myth-for him it was a truth from which humanity needed to be freed. Hence, the great methodological emphasis in the Arcades Project on the idea of awakening-awakening from a dream or from the compulsions of myth.

Benjamin's fascination with the concept of nihilism helps us account for the peculiar relationship in his thinking between periods of decline and redemption-an association suggestive of the doctrines of negative theology. One of the first to perceive the import of these two poles in his thought was Scholem, who observes that:

an apocalyptic element of destructiveness is preserved in the metamorphosis undergone in his writing by the messianic idea. . . The noble and positive power of destruction-too long (in his view) denied due recognition thanks to the one-sided, undialectical, and dilettantish apotheosis of 'creativity' - now becomes an aspect of redemption. ${ }^{19}$

The relation between these two concepts, moreover, goes far toward explaining the-at first glance peculiar-link he always emphasized between his theologically oriented 1925 Origin of German Tragic Drama and the quasi-Marxist Arcades Project. ${ }^{20}$ For both works seek to highlight manifestations of cultural decline (mourning-plays and arcades) in order to cull from them dormant potentials for transcendence. 
One might say that, in a Nietzschean spirit, Benjamin identifies with the doctrines of "active nihilism": the conviction that if something is falling, it should be given a final push. ${ }^{21}$ For only at the point where the process of cultural decay is consummated might a dialectical reversal occur-something, moreover, that is never a certainty.

Already in his surrealism essay (1929), Benjamin speaks rhapsodically of "the Satanism of a Rimbaud and a Lautreamont." Along with Dostoyevsky, their writings give birth to "the cult of evil as a political device ... to disinfect and isolate against all moralizing dilettantism." 22 Their work represents a thoroughgoing renunciation of the "affirmative character of culture" (Marcuse) as practiced by bourgeois aestheticism. It breaks definitively with a cultural practice, from romanticism to art for art's sake, that provides the literary precipitate of experience in recompense for the experience itself. It stands as a subterranean, nonliterary literary complement (insofar as their works have ceased to be "literature") to the wave of anarchism that first made its appearance in mid-nineteenth-century Europe. For it was the anarchists who first initiated a concept of radical freedom that expressed a total refusal to compromise with the blandishments of the existing social regime. In sum, their work signifies the advent of a spirit of intransigent cultural nihilism, as a consequence of which bourgeois art begins to divest itself of its "aura": the idea that the beautiful illusion of art is meant to provide aesthetic compensation for society's failings. Their attitude would culminate in the tradition-shattering ethos of the twentieth-century avant-gardes, dadaism, futurism, and, of course, surrealism. Of Breton and company Benjamin famously observes: "No one before these visionaries and augurs perceived how destitution-not only social but architectonic, the poverty of interiors, enslaved and enslaving objectscan be suddenly transformed into revolutionary nihilism" 23 - that is, into an attitude of thoroughgoing and uncompromising cultural radicalism.

It is the same sensibility that provokes Benjamin's profound identification with the "destructive character" who appreciates "how immensely the world is simplified when tested for its worthiness for destruction." The destructive character is anything but goal-oriented and devoid of an overarching vision of the way the world should be. "He has few needs, and the least of them is to know what will re- 
place what has been destroyed." 24 It was in the same spirit that he enthusiastically cited a remark of Adolf Loos: "If human work consists only of destruction, it is truly human, natural, noble work." 25

These sentiments also account for what Benjamin found attractive about communist politics. From the very beginning, he acknowledged his profound disinterest in communist goals. Nor was he at all moved by its crude epistemological stance. On one occasion he openly mocks the "inadequate materialist metaphysic" of diamat, which, needless to say, remained incompatible with Benjamin's abiding interest in the relationship between politics and theology. ${ }^{26}$ Instead, communism attracted him as an approach to political radicalism, as a form of "activism," which valued action for its own sake. Moreover, in Benjamin's eyes it was a politics that viewed the totality of inherited social forms nihilistically, with a view to their imminent destruction.

Benjamin would employ the theme of "anthropological nihilism" as one of the subheadings for the Arcades Project. He was aware, however, that by flirting with this problematic, his thought had entered into dangerous proximity with a fascist sensibility that in Germany and Italy had already triumphed, and which threatened to engulf Europe. Fascism, too, placed great emphasis on the need to destroy: an avowedly nihilistic "aesthetics of horror" formed a key component of the fascist worldview. ${ }^{27}$ Hence, Benjamin saw the need to distance his own "conservative revolutionary" tendencieshis inclination to view radical destruction as a necessary prerequisite for cultural renewal-from those of his proto-fascist contemporaries, such as Gottfried Benn, C. J. Jung, Ernst Jünger, Ludwig Klages, and Carl Schmitt.

Thus, to the anthropological nihilism of the conservative revolutionaries, Benjamin counterposes his own notion of "anthropological materialism." Not only was this theory intended as a counterweight to the "aesthetics of horror" purveyed by Benn, Jünger, et al.; it was also meant as a forceful rejoinder to the values of Western humanism as propagated by the representatives of German idealism. For the events leading up to World War I had shown how readily the German idealist tradition could be chauvinistically reinterpreted-for example, in the concept of Germany qua Kulturnation, which the mandarin intelligentsia employed as a justification for Germany's entitlement to geopolitical hegemony within Europe. ${ }^{28}$ 
Anthropological materialism was Benjamin's way of attempting to substitute, as he put it, a "more real humanism" for the bankrupt, sham humanism, whose ineffectuality under present historical circumstances seemed self-evident. It was a way of denigrating humanity in its current, degraded state in order better to prepare the ground for its final, eschatological renewal-just as, according to Benjamin, in order "to understand a humanity that proves itself by destruction," one must appreciate Klee's Angelus Novus, "who preferred to free men by taking from them, rather than make them happy by giving to them." 29 These remarks, from Benjamin's essay on Karl Kraus, represent an essential complement to his discussion of the angel of history in the "Theses" and demonstrate how integral the relationship between destruction and renewal was for his thought.

As a basis for real humanism, anthropological materialism differed from the scientific materialism of orthodox Marxism. Benjamin had already introduced the concept in his surrealism essay, the fount of so much of his later thought. He associates it with the "nihilistic poetics" of Büchner, Nietzsche, Rimbaud, and, of course, the surrealists themselves. As such, it bears an essential relation to the key concept of that essay, profane illumination. It expresses Benjamin's "revisionist" conclusion that revolution is less a question of socializing the means of production than a matter of bodilycollective exaltation; in essence, society must become "surrealized," it must become a collective locus of profane illumination. As Benjamin concludes his essay: "Only when in technology body and image so interpenetrate that all revolutionary tension becomes bodily collective innervation, and all the bodily innervations of the collective become revolutionary discharge, has reality transcended itself to the extent demanded by the Communist Manifesto." It is the tradition of anthropological materialism, culminating in the surrealist effort to efface the boundaries separating art and life, that alone has realized concretely what it might mean "to win the energies of intoxication for the revolution." 30

An interest in the relation between revolution and intoxication gets to the very heart of Benjamin's cultural-revolutionary program for the Arcades Project. It also goes far toward explaining why his momentous encounter with surrealism in the 1920 s would become the key influence in defining that program. 
The proximity in which Benjamin's destructive-regenerative critique stands to analogous tendencies on the German right bears further examination. It is a proximity that has been widely noted but rarely analyzed in detail. Perhaps the first to detect its import was Scholem, who once observed that Benjamin

had an extraordinarily precise and delicate feel for the subversive elements in the oeuvre of great authors. He was able to perceive the subterranean rumbling of revolution even in the case of authors whose worldview bore reactionary traits; generally he was keenly aware of what he called "the strange interplay between reactionary theory and revolutionary practice." 31

Habermas has pointed out a similar phenomenon: Benjamin's marked fascination with authors and ideas that had become standard points of reference for the right-wing critique of modern society: "Benjamin, who uncovered the prehistoric world by way of Bachofen, knew [Alfred] Schuler, appreciated Klages, and corresponded with Carl Schmitt - this Benjamin, as a Jewish intellectual in 1920s Berlin could still not ignore where his (and our) enemies stood." This leads him to conclude that Benjamin's theory of experience would be best described as a "conservative reactionary hermeneutic." 32

Like Bloch, Benjamin realized that the left's unreflective progressivism was in danger of neglecting the value of those "noncontemporaneous" elements whose revolutionary promise was being commandeered by the forces of political reaction: elements pertaining to the values of tradition, Gemeinschaft, myth, religiosity, and so forth; elements that had been brusquely marginalized by the rush toward modernity, which, in his view, left the world a disenchanted, impoverished, well-nigh meaningless place. It was, therefore, only natural that Benjamin would seek to mobilize potentials for the critique of modernity that had been provided by reactionary thinkers. They alone realized the latent capacity to heal the lacerated social totality of modernity. Such an alliance of convenience suggested itself to Benjamin insofar as the right-wing critique of Zivilisation (a characteristic term of disparagement for a generation that grew up under the tutelage of Nietzsche and Spengler, though, one which Benjamin carefully avoided) proved more intransigent, more thoroughgoing, and less willing to compromise with the normative pre- 
suppositions of the modern world than left-wing criticism. In the last analysis, both social democrats and communists (let alone liberals and "mere" democrats, who, from the rarified standpoint of theological criticism, are hardly worth mentioning) proved overly enamored with the logic of "progress," with which Benjamin believed one needed to break at all costs-even that of forming problematical theoretical alliances.

To be sure, Benjamin went to great lengths to transform elements of the conservative revolutionary critique of modernity in order to make them serviceable for a left-wing political agenda. But with the advantage of historical distance, one realizes just how much of an overlap exists between the cultural left and right in the case of the interwar generation. For critically minded German intellectuals of this period, the vitalistic critique of Zivilisation had become an obligatory intellectual rite of passage.

It is in this spirit that recent critics have justifiably tried to show the parallels between Lebensphilosophie and the philosophy of history adumbrated by Horkheimer and Adorno in Dialectic of Enlightenment. It would be wrong to emphasize the similarities at the expense of the differences. For unless these differences, which are no less important, are taken into account, the two approaches risk becoming, in essence, "the same"-which is far from being the case. ${ }^{33}$ But in fact both Klages and Dialectic of Enlightenment purvey an anthropologically rooted critique of civilization, in which the central culprit is ratiocination - a faculty that places humanity at odds with both inner and outer nature. In essence, contemporary civilization suffers from an excess of "intellect" over "life." A reconciliation with nature-both inner and outer-is the telos that guides both approaches to Kulturkritik. ${ }^{34}$

These sentiments, far from being alien to Benjamin, are among the central preoccupations of his work (see, for example, the important fragment, "On the Doctrine of the Similar"). I have argued elsewhere that the philosophy of history of Dialectic of Enlightenment is, via the mediation of Adorno, a specifically Benjaminian inheritance. ${ }^{35}$ The critique of progress and the understanding of history as loss and decline, as well as the central theme concerning the interrelationship between enlightenment and myth, would be inconceivable without the precedent of his "Theses on the Philosophy of History" and other texts. 
But unless one specifies precisely what aspects of the vitalist critique Benjamin deemed worthy of appropriation, one risks proceeding by insinuation rather than sound argument. For example, we know that his theory of the "decline of the aura" was in part derived from a member of the George-circle, Alfred Schuler. Yet, in Benjamin's work Schuler's ideas appear radically transformed, to the point where Schuler's predominantly mythological interpretation of it is barely visible.

A similar claim can be made in the case of what Benjamin may have found of value in the work of Carl Schmitt. Schmitt's work emphasizes the paramountcy of the "state of exception" (Ausnahmezustand) in determining sovereignty. It was an approach that Benjamin found methodologically suggestive for understanding the endemic political instability depicted in seventeenth-century tragic drama. Yet, the existence of a fairly ingratiating 1930 letter to Schmitt notwithstanding, to claim that Benjamin's understanding of contemporary politics was substantively indebted to Schmitt (as indeed some have) is to exaggerate. ${ }^{36}$

But in the case of Benjamin and Klages, there is something much more essential at stake. Benjamin was an enthusiast of Klages early on. In 1913 Klages delivered a famous lecture on "Man and Earth" at Hohe Meissner, a legendary German youth movement site. Because of its provocative anticivilizational and ecological themes, the lecture subsequently acquired canonical status among youth movement members. Benjamin visited Klages in Munich the next year and invited him to speak to the Berlin youth movement group (the Free Student Society) over which Benjamin presided.

Benjamin later developed a keen interest in Klages' 1922 work, On Cosmogonic Eros, praising the book in a letter to Klages the following year. Moreover, his essay on Johann Jakob Bachofen (1935) is punctuated by a long discussion of Klages, whom he praises on a number of counts. ${ }^{37}$ According to Benjamin, the chthonic theory of archaic images (Urbilder) that Klages develops in his 1922 work stands opposed to "representations" or the domain of the rational concept. Representations pertain to the "intellect" (Geist), which is characterized by "utilitarian views" and an interest in "usurpation." The image, conversely, is a direct expression of the soul and relates to the domain of "symbolic intelligence." As such, it stands opposed to the abstract intellectualism of the rational concept, 
which, from the perspective of Lebensphilosophie, represents the basis of a mechanistic and soulless bourgeois Zivilisation. On all these points, it would seem, Benjamin could not be more in agreement with Klages.

It is not hard to discern what it was about the vitalistic critique of modern life he sought to appropriate for the ends of left-wing Kulturkritik. Despite his explicit reservations about Klages' perspective (he calls it a "system without issue that loses itself in a threatening prophecy addressed to a humanity that has allowed itself to be misled by the insinuations of the intellect"), he concludes his discussion with the following words of praise: "It is true that despite its provocative and sinister side, this philosophy, by virtue of the shrewdness of its analyses, the profundity of its views, and the level of its discussions, is infinitely superior to the appropriations of Bachofen that have been attempted by the official professors of German fascism." 38

Benjamin would remark to Adorno that the Bachofen manuscript, in which he attempts to work out in detail his relation to Klages, bore great relevance to their most intimate shared theoretical concerns ("Es liesse sich bei dieser Gelgegenheit viel zu unsern eigensten Dingen sagen"). ${ }^{39}$ And in an earlier letter, Adorno had already noted that Klages' 'doctrine of the 'phenomenon' in the 'Reality of Images' [a chapter from volume 3 of The Intellect as Antagonist of the Soul] stands in the closest proximity to our questions." 40 He goes on to observe that: "it is precisely here that the boundary line between archaic and dialectical images lies, or, as I once stipulated against Brecht, a materialistic theory of ideas."

In essence, the success of their mutual philosophical project hinged on a successful materialist articulation of the doctrine of dialectical images. It was Klages who, as Adorno acknowledges in the lines just cited, had unquestionably gone the farthest in the direction of outlining a doctrine of images that was decidedly opposed to the predominant, rationalist approaches to the theory of knowledge-neo-Kantianism, positivism, and scientific Marxism. Yet, in his theory, such images appeared as eternal, timeless embodiments of the human soul. With Klages the image possessed an avowedly transhistorical, mythological status. For Benjamin and Adorno, therefore, the key to redeeming Klages' theory lay in historicizing the doctrine of images: to break decisively with their timeless, ahistorical, myth- 
ological character by saturating them with historical content. Whereas Klages and other representatives of Lebensphilosophie viewed the contemporary cultural crisis as the manifestation of an eternal cosmological struggle between "reason" and "life," Adorno and Benjamin sought to give the crisis historical definition and scope by revealing it as a crisis of capitalism. To the imagistic theory of truth per se, however, they had few specific objections. Instead, they viewed it as a valuable epistemological alternative to the fatal rationalscientific biases of late capitalist society.

In this approach, one sees in nuce the methodological plan for both Benjamin's Arcades Project and Adorno's own mature theory of knowledge - which, 'following Benjamin's lead, he would characterize as thinking in "constellations." ${ }^{11}$ It should come as little surprise, then, if Benjamin, in one of the more revealing (if characteristically terse) methodological directives for the Arcades Project, remarks: "to link heightened visibility [Anschaulichkeit] with the Marxist method" (V, 578). Here, "visuality" signifies a clear reference to the theory of images.

And thus, one of the conceptual keys to the project's completion lay in a risky merger of Marx and Klages. Because of their nondiscursive nature, Benjamin viewed images as potentially superior to rational theories of cognition, which only aggravate the post-Enlightenment march of "disenchantment." Yet, the important twist added by Benjamin's theory of modernity suggests that, contra Weber and Marx, the disenchantment of the world is accompanied by a reenchantment: by a resurgence of mythological forces in modern garb. This reenchantment of the world was integrally related to the quasi-utopian wish-images that pervaded the phenomenal manifestations, the cultural superstructure, of modern capitalism: manifestations such as world-exhibitions, iron constructions, panoramas, interiors, museums, lighting, photography - not to mention the arcades themselves, the consummate dream-images of nineteenth-century commodity culture.

In Dialectic of Enlightenment, Horkheimer and Adorno would explicitly adopt Benjamin's view concerning the entwinement of myth and Enlightenment, arguing that in the modern era Enlightenment degenerates into myth (e.g., the myth of "scientific progress"), just as myth is already a form of Enlightenment (an early form of world-demystification). Yet, in Benjamin's case, the idea of 
a recrudescence of mythical elements in the modern era was a concept of distinctly Klagean provenance. For Klages the archaic images corresponded to a primeval soul-world that stood opposed to the progressive disintegration of experience in modernity. However, owing to this atrophy of experience, under present social conditions these images were only accessible once the conscious mind was caught off guard: in day-dreams, trances, or when confronted with experiences that disrupted the normal patterns of rational thought. In his essay "On Dream-Consciousness," a work that Benjamin admired, ${ }^{42}$ Klages sought to provide a phenomenological account of the everyday circumstances that could lead to renewed contact with archaic images:

if in the stillness of the night we hear an automobile pass by and the sound gradually trails off into the distance; when viewing fireworks from afar or noiseless sheet-lightning; when returning to one's native surroundings after a several year interim marked by a perhaps stormy life; or, conversely, when visiting places of uncommon strangeness; . . . often when traveling by train, assuming that one has a compartment to oneself; occasionally in moments of great exhaustion, of hopeless despondency, of unbearable pain, as well as usually after taking whatever type of narcotic. ${ }^{43}$

Here, moreover, the parallel with Jünger's theory of experience, as developed in books such as The Adventuresome Heart, is quite relevant. All three, Benjamin, Klages, and Jünger, were concerned with the diminution of the potential for qualitative experience following the world-historical transition from Gemeinschaft to Gesellschaft. Like Benjamin, Jünger feared that an increasingly mechanized modern cosmos and the progressive industrialization of the lifeworld would banish prospects for superior, self-transformative experiences. In a similar vein, Karl-Heinz Bohrer has convincingly shown how Benjamin's identification with the shock-aesthetics of the twentieth century avant-garde resembles Jünger's attraction to extreme situations (Grenzfälle), rapture, and transgression-whose paramount instance was proximity to death in war.

In a recent essay, Axel Honneth has commented on the parallels between Benjamin and Jünger and the "anthropological materialism" on which their theories of experience are based:

Jünger's anthropological materialism seized on extraordinary states, which, as in Benjamin, are circumscribed with the help of categories casually adopted from Bergson: in situations of danger, which originate from the 
child's natural helplessness, in the warrior's confrontation with the danger of being killed, and for those intoxicated in the maelstrom of the loss of self-in these situations a series of self-evident values or "standards of the heart" are revealed from the magical perspective. . . These moments of magical rapture have a privileged status. . . . Again and again, Jünger's diary-like notes end in the description of corresponding situations of magical rapture: intoxication, sleep, and the danger of dying are for him keys to that one experience that in a unique way establishes a correspondence between soul and world because it is not shaped by an attitude of instrumental control. ${ }^{44}$

Of course, Jünger and Benjamin take their concern for the atrophy of historical experience in radically different directions. As an aristocratic radical in the tradition of Nietzsche, ${ }^{45}$ Jünger's magical realism pushes in the direction of a restoration of the values of social hierarchy and martial heroism. Only at the end of The Adventuresome Heart does he divulge the figure on whom he places his hopes: the "Prussian anarchist." "Armed only with the categorical imperative of the heart," he roams through the forlorn landscape of the historical present as the apocalyptical standard-bearer of a new social order. ${ }^{46}$ In The Worker (1932) he argues that an enfeebled modernity can be redeemed only if society as a whole is reorganized along military lines. Benjamin finds this line of thinking abhorrently fascistic, as his scathing review of the 1930 anthology edited by Jünger, War and Warriors ("Theories of German Fascism"), suggests. ${ }^{47}$ Instead, he places his hope in a messianic theory of history-a marriage, as it were, of Kabbalah and Marx-whereby the promises of redeemed life are generalized and rendered profane.

At the same time, both Benjamin and Jünger are convinced that a surfeit of consciousness-a peculiarly modern affliction (in The Genealogy of Morals, Nietzsche already speaks of the virtues of "active forgetting")-works to the disadvantage of heightened states of experience, whose prerequisite seems to be a capacity to dissolve the self in ever greater experiential totalities: the "collective unconscious" (Jung); the cosmos (Klages); the Parmenidean "one," and so forth.

In his remarks on Freud and Bergson in "On Some Motifs in Baudelaire," Benjamin makes precisely this point. He laments the fact that in the modern world the powers of consciousness must be enhanced as a defense against the "shocks" of everyday life (a prob- 
lem that is especially acute in the modern metropolis, the locus classicus of shock experience). As a result of this need for a constantly vigilant consciousness, our natural and spontaneous capacities for experience are necessarily diminished.

This accounts for the great methodological significance that Benjamin attaches to the celebration of involuntary (nonconscious) memory in Proust. Only the systematic labor of involuntary memory can recover memory traces that have been lost to conscious remembrance owing to the institutionalized struggle for self-preservation that modern society has become. It also accounts for the importance of Bergson (who occupies a similar niche of honor in Jünger's work), who was the first to consider memory as the key to the theory of experience (though Benjamin would sharply criticize Bergson's alienation from genuine historical experience).

According to Benjamin, the attempt to wrest a genuine concept of experience from the benumbing uniformity of modern Zivilisation has proceeded in two opposed directions. The first stems from Lebensphilosophie, which extols the notion of Erlebnis. Its characteristic features are: (1) a steadfast aversion to sociohistorical categories and concerns; and (2) a corresponding tendency to seek refuge in the manifestly ahistorical spheres of nature and myth (a late inheritance of German romanticism). These tendencies culminate in the doctrines of Jung and Klages who, Benjamin observes, "made common cause with fascism." "Towering above this literature," he counters, "is Bergson's early monumental work, Matter and Memory. . . The title suggests that it regards the structure of memory as decisive for the philosophical pattern of experience. Experience is indeed a matter of tradition, in collective existence as in private life." Proust is the proper heir to Bergson. For he realized that, whereas an experienced event is finite, "a remembered event is infinite because it is key to everything that happened after it and before it." 48 In the Arcades Project, Benjamin sought to use rapidly fading historical memories as precisely such a key.

It is at this point that the dilemma involved in Benjamin's later theory of experience, whose consummation was to have been the Arcades Project, becomes clear. The dilemma may be stated as follows: Benjamin's project focused on a critique of modernity from the standpoint of a theory of experience. To this end, he received very little theoretical aid and comfort from thinkers on the left. 
Instead, their Panglossian conviction that "history was on their side" (in the "Theses," Benjamin caustically observes that "Nothing has corrupted the German working class so much as the notion that it was moving with the current") showed that they were committed to an Enlightenment vision of progress that, in its essentials, barely differed from the bourgeois worldview they were seeking to counter. Moreover, the "cult of labor" that had been established by the Social Democrats (and presciently exposed by Marx in his "Critique of the Gotha Program") amounted to little more than a socialist version of the Protestant ethic. Benjamin found the alacrity with which the established left-wing parties proclaimed the exploitation of nature as a desirable and valid goal especially appalling. It represented a betrayal of the noninstrumental, poetic vision of a reconciliation between humanity and nature that had been proposed by utopian socialists such as Fourier.

It is a stark and incontestable reality that Benjamin found he had more in common with the theoretical strategies of right-wing intellectuals than he did with contemporaries on the left. If one were interested in an uncompromising critique of modernity from the standpoint of the diminution of experiential wholeness (a standpoint which, to be sure, always entailed a somewhat romanticized vision of the past), the position represented by Weimar's numerous and influential Zivilisationskritiker ("critics of civilization") seemed to have much to recommend it.

Early on, Benjamin would, in a letter to Scholem, speak of a "theoretical confrontation with Bachofen and Klages [as] indispensable." 49 A few years later he would characterize The Intellect as the Antagonist of the Soul as "a great philosophical work," despite the avowedly anti-Semitic leanings of the book's author. ${ }^{50}$

Benjamin's concept of the "collective unconscious"-one of the methodological keys to the Arcades Project - was explicitly derived from Jung. In the mid-1930s, as the fascistic implications of Jung's theories became apparent, Benjamin came to view a theoretical self-clarification vis-à-vis Jung as an imperative task. He alludes to this project in a 1937 letter to Scholem: "I wish to secure certain methodological fundaments of 'Paris Arcades' via a confrontation with the theories of Jung-especially those of the archaic image and the collective unconscious." 51 His proposed study of the differences separating his utilization of these concepts from that of Jung and 
Klages was rebuffed by the Institute of Social Research. Undoubtedly, Horkheimer et al. were convinced that an engagement with Jung and Klages, even for the sake of broadening the potentials of left-wing Kulturkritik, was wholly unacceptable under present historical circumstances, in which the linkages between vitalism and fascist ideology were present for all to see. ${ }^{52}$ Adorno had already vehemently criticized Benjamin's uncritical reliance on their theories in "Paris, Capital of the Nineteenth Century" (the Arcades Expose) - especially with reference to Benjamin's attempt to view the classless society of prehistory as a "golden age": "Thus disenchantment of the dialectical image leads directly to purely mythical thinking, and here Klages appears as a danger, as did Jung earlier." ${ }^{53}$

To say that Benjamin found many aspects of the national revolutionary critique of modernity methodologically congenial, that he perceived figures such as Jung, Klages, Schuler, and Max Kommerell (the latter three were all members of the George-Kreis) ${ }^{54}$ as kindred intellectual spirits, should not be treated as evidence that the Arcades Project was inherently flawed. Though he assimilated their views, they were by no means the only major influences: the surrealists, the utopian socialists, Proust, and Baudelaire were equally significant. In different ways, all contributed to Benjamin's unique and brilliant research program of the 1930s: a secular redemption of modern mythology; a materialist recovery of the phenomenal manifestations of the nineteenth-century "dreaming-collective." 55

Moreover, Benjamin hardly appropriated the doctrines of the Weimar's antidemocratic intellectuals tel quel. Instead, he sought to transform them in accordance with his own idiosyncratic theoretical perspective and needs. He was convinced that their theories had addressed the problem of the breakdown of experience in the modern world in a way that the intellectual paradigms of Enlightenment provenance-neo-Kantianism, social scientific empiricism, logical positivism, historicism, and so forth-had not. The anti-intellectual intellectuals of Germany's conservative revolution were agreed that "thinking was no longer the highest vocation of humanity, rather experiencing, feeling, seeing . . and the actualization of myth." 56

From his earliest writings on experience, knowledge, and language, Benjamin displayed a considerable measure of sympathy for such views, though he was also keenly aware of their destructive potential. This accounts for his figurative or "imagistic" recasting of 
the theory of knowledge in the Trauerspiel book as a theory of constellations. A similar impulse explains his reliance on the dialectical image as the methodological crux of the Arcades Project. For in his view, a theory of knowledge that was graphically oriented possessed a distinct epistemological advantage over approaches that relied on discursive or propositional truth alone. From the standpoint of the philosophy of life, therefore, one could accede to realms of experience and knowledge that exclusively rational modes of cognition had, to their own detriment, left unexplored. In all of these respects, it is clear that the vitalist fascination with archaic images, the unconscious, dreams, shocks, collective forms of experience, and states of ecstasy in which the unity of the self dissolves, represented for Benjamin an important complement to what he found of value in the profane illuminations of the surrealists. Reactionary thought, too, contained "energies of intoxication" that needed to be won over for the revolution. But in this case, it would not be a Revolution von Rechts-a "revolution from the right." 57

Could the effort to recast historical materialism as a theory of experience be successful? Would it be possible to weld together two perspectives that have traditionally been at odds without succumbing to the risks, as Benjamin says in his surrealism essay, of a "poetic politics"?

Many have been skeptical of such attempts. In his extremely lucid evaluation of Benjamin's thought and legacy, Habermas expresses a dissenting view. The attempt to reconcile historical materialism and a redemptory hermeneutics must fail, he observes,

because the materialist theory of social development cannot simply be fitted into the anarchical conception of now-times [Jetztzeiten] that intermittently break through fate as if from above. Historical materialism, which reckons on progressive steps not only in the dimension of productive forces but in that of domination as well, cannot be covered over with an antievolutionary conception of history as with a monk's cowl. ${ }^{58}$

In other words, in his writings of the 1930s Benjamin tried to reconcile the irreconcilable: a theory that takes claims concerning progressive historical development seriously (claims for which Benjamin certainly did not show much patience) and a messianic view of history that believes, conversely, that only those breakthroughs are meaningful that present themselves as ruptures with the contin- 
uum of history as it has been constituted thus far. In Habermas' view, then, a theory of experience and historical materialism are not inherently incompatible. They do operate at cross purposes, however, when both are subtended by a messianic perspective that perceives the realms of historical and messianic time as constitutionally opposed. Benjamin could counter (and does) by claiming that the messianic-utopian potentials on which a materialist theory of experience focuses are wholly immanent and thus in no way dependent on a deus ex machina, such as "the coming of the Messiah." The description of "now-time" as a moment of "messianic cessation of happening" in the "Theses on the Philosophy of History" must therefore be understood metaphorically. Even if this claim were true, it still leaves unanswered Habermas' initial question as to whether a theory that is so antithetically disposed toward the claims of social evolution-on which, clearly, Marxism stakes so much-can be reconciled with historical materialism as it has been traditionally conceived.

In order to answer the question of whether Benjamin's theory of experience remains ultimately compatible with the claims of Marxist thought, we must turn to a consideration of the thirteen year undertaking that Benjamin hoped would reconcile these two approaches - the Arcades Project.

The hermeneutic difficulties of approaching the Arcades Project are compounded by its status as a torso. The editors of Benjamin's collected works insinuate a false integrity by referring to it as the "Passagen-Werk." It would be perhaps more accurately dubbed the "Passagen-Arbeit" in order to suggest that, instead of constituting a whole, it represents a work-in-progress, on which Benjamin labored fitfully from 1927 until shortly before his death in September 1940 (moreover, this was the designation that Benjamin himself used in his letters to describe his study).

There are those who would like, following a well-established German literary tradition, to celebrate its fragmentariness-an attitude that would seem especially apt in the case of Benjamin for whom a preoccupation with fragments and ruins became, as it were, 
a literary signature. Yet, to romanticize its inconsummate character serves only to further mystify a document whose hermeticism implores sober decoding. Otherwise one risks consigning Benjamin's oeuvre to the belle-lettrism he deplored.

The text is patently unreconstructible as a whole. Many of its "files" (Konvoluten) - in all, thirty-five, organized according to subject headings-consist largely of uncommented citations that Benjamin intended either as references or material ultimately to be incorporated into the finished version. Benjamin's own commentaries (e.g.: "The dialectical image is a flashing image. Thus, the past must be seized as a flashing image in the now of recognizability") ${ }^{59}$ are characteristically lapidary, but, for that reason, far from easy to decipher. Though the massive quantities of citations he assembled are highly suggestive, it is largely a matter of conjecture as to how they would have been fashioned into a coherent whole. For that matter, there has been ample speculation, far from irrelevant, as to whether the project, which had gone through so many alterations in methodology, form, and substance, was in principle completable $\rightarrow$ so refractory and unwieldy had those vast quantities of citations become.

A minor scholarly tempest was unleashed when two researchers concluded upon perusing a batch of newly discovered Benjamin manuscripts found among the literary estate of Georges Bataille that, in the late 1930s, Benjamin had simply abandoned work on the Arcades Project and instead decided to concentrate his energies exclusively on the Baudelaire book. As evidence for their case they contended that as of 1938, Benjamin's notes were entered exclusively under the Baudelaire rubric (file "J") ${ }^{60}$ These claims have been vigorously contested by the editors of Benjamin's collected works and others. ${ }^{61}$ Yet, what one can indeed conclude from an examination of Benjamin's Paris manuscripts is that the Arcades Project was even further away from completion than expected: of the six hundred odd titles Benjamin had inventoried in the course of his many years of research, only one-third had been consulted; and, of these, only fifty or so had actually been incorporated in the "Notes and $\mathrm{Ma}$ terials" section of the Passagenwerk.62

Whereas in the 1935 "Exposé" the work on Baudelaire constituted only one chapter among six (the other five were: arcades, panoramas, world exhibitions, the interior, and barricades), in 1937, at the urging of the Institute for Social Research, it grew into a sep- 
arate book, only one part of which was ever brought to completion ("Paris of the Second Empire in Baudelaire"). Susan Buck-Morss speculates that, so committed was Benjamin to the Arcades Project, that all six chapters might have eventually been turned into independent books. ${ }^{63}$ But considering that only one-third of the Baudelaire study was ever written, what chance might he have stood of completing, along with it, five additional Passagenwerk-derived monographs, even had his material conditions of life been optimal?

Moreover, in evaluating the project one must keep in mind that Benjamin's own intentions changed several times. The first surrealist-inspired version was called "Paris Arcades: A Dialectical Fantasy." There Benjamin refers to the arcades as "the architectural constructions in which we relive, as if in a dream, the life of our parents and grandparents, just as the embryo in the womb relives the life of animals." 64 In these early notes for the Arcades Project, Benjamin seemed much more infatuated with the manifest content of his material-its potential for enchantment à la surrealism-than with the moment of revolutionary awakening. But the essential conception of the nineteenth century as a modern mythology was in place. Unlike bourgeois and Marxist theories of history that viewed technology as emancipatory and progressive, Benjamin viewed it as responsible for a recrudescence of myth. It succeeded in creating a dream-landscape and consciousness, a type of kitsch-dominated, retrograde utopia. The moment of "ambiguity" would prove crucial, since it expressed the fact that this modern mythology was not something purely and simply regressive, but contained a utopian moment. It was the duty of the historical materialist to flush out this element. Therein lay the indispensable role of the dialectical image. It would establish a unique and revolutionary relation to the past. Unlike the positivist mentality of nineteenth-century historicism, which aimed at a reconstruction of the past as such, the dialectical image sought to situate the past in relationship to the revolutionary needs of the historical present. It was concerned with the "actualization" (Vergegenwärtigung) of the past, rather than recreating it "as it really was."

In the early 1930s Benjamin had virtually ceased his labors on the "Paris Arcades." When he resumed his work in 1934, his conception had changed dramatically. The earlier subtitle, "A Dialectical Fantasy," had been dropped. Whereas the first version of the 
project had focused exclusively on the arcades, in the new formulation, the arcades, while still central, were demoted to merely one chapter among six. Moreover, in its new incarnation, "Paris, Capital of the Nineteenth Century," the project took on a less literary and more historical focus. Benjamin seemed determined not to allow himself to succumb, as had the surrealists, to the magic spell of modern mythology. For this was a spell that needed to be broken. At the same time, to break the spell entailed a profound redemptory moment. For, qua fairy tale, modernity contained a promise of happiness which it fell to the critic to redeem.

But the question remains: did Benjamin in his unfinished masterwork ever really free himself from an infatuation with the modern mythology that had been incited by the works of surrealist authors such as Breton, Aragon, and others? Were his dialectical images sufficiently disenchanted to actually break the magic spell? Or did they merely perpetuate it, thereby purveying a type of "enchantment to the second power"? These are difficult questions to answer given the inconsummate status of the Arcades Project. But they are nonetheless indispensable if one is to accede to the essence of what Benjamin hoped to achieve.

We know that Benjamin, inspired by the surrealists, had intended montage as the project's methodological key. Montage-a juxtaposition of disparate elements, in which no one element takes precedence over another-was meant as the organizing principle of the dialectical images. Benjamin had always been unambiguous on this point:

Method of this work: literary montage. I have nothing to say. Only to show. I will make off with nothing valuable and allow myself no clever turns of phrase. Only the refuse and waste: which I will not inventory but instead allow to come into their own in the only way possible: I will make use of them.

This work must raise the art of citing without quotations marks to the highest level. Its theory is most intimately linked to that of montage. ${ }^{65}$

Precisely what Benjamin might have meant by "literary montage" as an organizing principle is open to interpretation. Adorno understood this idea quite literally, thereby confirming his direct fears: that Benjamin intended to construct the Arcades Project as a 
montage of citations divested of supporting commentary. In retrospect, this view seems untenable. The arcades-related texts that have survived, such as "The Paris of the Second Empire in Baudelaire" (which Benjamin once referred to as a "miniature model" of the Arcades Project), are hardly devoid of commentary - though it certainly remains sparse. ${ }^{66}$

Nevertheless, Adorno's misgivings about the potential for abuse that lay in an excessive reliance on montage were well founded. They address the fact that at times Benjamin tended to view the theoretical implications of his material-the "refuse and waste" to which he refers above - as nearly self-evident, which was far from true. When Adorno, in the late 1940s, first gained access to the "Notes and Material" for the Arcades Project, he expressed these reservations quite pointedly in a letter to Scholem:

At the beginning of the previous year [1948] I finally received the arcades material that had been hidden in the Bibliothèque Nationale. Last summer I worked through the material exhaustively, and problems arose that I must discuss with you. The most difficult aspect is the extraordinary inattention to theoretically formulated ideas as opposed to the enormous store of excerpts. That may in part be explained from the idea that was explicitly expressed on one occasion (and which to me is problematical) that the work should be merely "assembled" [montieren]; that is, compiled from citations, such that the theory leaps forth without one having to append it as interpretation. Were that to have been possible, only Benjamin himself would have been able to accomplish it; whereas I have always been faithful to the standpoint of the Hegelian phenomenology of spirit, according to which the movement of the concept, of the matter at hand, is coincident with the explicit thought process of the reflecting subject. Only the authority of sacred texts would stand as a refutation of this conception, and the Arcades project has avoided precisely this idea. If one takes, as I would like, the montage idea not entirely à la lettre, it could have easily turned out that Benjamin's ideas could have been formed from countless citations.

A further difficulty consists in the fact that although there exists a general plan for the work and a careful ordering of the material according to subject headings, there is no really detailed schema that, for example, would have permitted one to complete the construction as Benjamin had intended. On the other hand, the unorganized publication of the material would not in the least be helpful, insofar as, as things now stand, in no way does the intention leap forth. ${ }^{67}$

Even had Benjamin abandoned the idea of montage in the strict sense - that is, as a theoretically unadulterated array of cita- 
tions-as now seems likely, it was far from clear that the basic theoretical difficulties of the work would thereby have been resolved. On the one hand, as Adorno points out in his letter, only the late Benjamin himself could have reconstituted the massive compilation of data as a meaningful whole. The ordering schemas he left behind-the two versions of "Paris, Capital of the Nineteenth Century" as well as the thirty-five odd subject headings to the "Notes and Materials" section-remained too fragmentary or allusive to serve as a reliable guide.

Moreover, it seems that even though in the course of his research Benjamin may have realized the potential risks involved in pure montage, he was never able to distance himself sufficiently from his fascination with this principle, which had become the hallmark of the 1920s avant-garde (surrealism, Soviet film, etc.).

In his correspondence of the mid-1930s, a related methodological keyword began to crop up: construction. As he remarks in a 1935 letter to Gretel Adorno: the "constructive element" would form the necessary complement to the compilation of materials. This was also his response to Theodor Adorno's objections to the division of chapters in the 1935 Exposé: "The arrangement [of the chapters] lacks the constructive moment. . . The constructive moment signifies for this book what the philosopher's stone means for alchemy." 68

That Benjamin insisted on drawing analogies with medieval science to explain what was at stake in the Arcades Project did not bode well for its fidelity to materialist principles. It also illustrates some of the perils of an approach that is committed to thinking in images: their indeterminacy cannot compensate for conceptual failings. In the last analysis, "construction" merely referred to the arrangement of materials. Fundamentally, it was as ascetic toward commentary as was montage. Moreover, the directives Benjamin gave as to how such an arrangement should proceed ("Articulating the past historically means ... seizing hold of a memory as it flares up in a moment of danger") lacked specificity. ${ }^{69}$

The materialist turn he sought to give concepts taken over from Jung and Klages, which were of central theoretical importance to the Arcades Project, would also prove ineffective. Jung's theory of the "collective unconscious" would play a key role in the 1935 Exposé, as would the notion of dream consciousness, which seemed to be derived in equal measure from surrealism, Klages, and Bloch. 
Benjamin was clearly enamored with Marx's famous claim in a letter to Ruge that "the world has long been dreaming of something that it can possess in reality only if it becomes conscious of it." He cites it approvingly in the section on "Theory of Knowledge" in the Arcades Project and goes on to claim that "the utilization of dream elements in awakening is the textbook example of dialectical thought." 70 His theory of dream consciousness has much in common with Bloch's notion of "dreaming toward the future." It is precisely in this sense that he employs Michelet's saying, "Every epoch dreams its successor," as a motto to introduce the central statement of method in the Exposé. For, the allegory-laden, commodity utopias of the nineteenth century engendered a proliferation of dream- and wishimages, a phantasmagoria, which humanity would be able to "possess in reality only if it becomes conscious of it." Benjamin associated the act of "becoming conscious" with the moment of awakening from the dream; it was an act which at the same time entailed a realization of the utopian potential contained in the dream.

In this way, Benjamin sought to recast the relationship between base and superstructure in orthodox Marxism. No longer was the superstructure a mere reflection of the base. Instead, it appeared as its "expression"; 71 an expression, however, that proved in crucial respects to be in advance of the base, insofar as, qua phantasmagoria, its wish-images foreshadow the utopia of a classless society.

Here is how Benjamin sought to fuse together the concepts of wish-image, dream, collective unconscious, and classless society in the 1935 Exposé:

To the form of the new means of production, which to begin with is still dominated by the old (Marx), there correspond images in the collective consciousness in which the new and the old are intermingled. These images are wish-images, and in them the collective seeks not only to transfigure, but also to transcend, the immaturity of the social product and the deficiencies of the social order of production. In these wish-images there also emerges a vigorous aspiration to break with what is out-dated-which means, however, with the most recent past. These tendencies turn the image-fantasy, which gains its initial stimulus from the new, back upon the primal past. In the dream in which every epoch sees in images the epoch which is to succeed it, the latter appears coupled with elements of prehistory-that is, of a classless society. The experiences of this society, which have their store-place in the collective unconscious, interact with the new 
to give birth to the utopias which leave their traces in a thousand configurations of life, from permanent buildings to ephemeral fashions. ${ }^{72}$

Benjamin viewed it as his task in the Arcades Project to unlock, via the employment of dialectical images, the utopian potential that lay dormant in the phenomenal manifestations of nineteenthcentury cultural life. Whereas Klages had sought to highlight the recurrence of archaic images in modern life, the images from the primal past that Benjamin sought to cull were the purportedly "materialist" images of a classless society. But the theory of the transhistorical persistence of archaic images was, in its essence, Klagean. The memory-traces of a classless society had been stored in the "collective unconscious" (Jung) and were then reactivated in the phantasmagoria of high capitalism. Marx once observed that humanity only sets itself tasks that it can solve. Benjamin believed that its most valuable potentials first appeared-albeit encoded-in dream form. If the phenomenal forms of nineteenth-century life represented a collective dream, then Benjamin's Arcades Project was a type of monumental Traumdeutung ("Interpretation of Dreams").

As the 1930s drew to a close, the prospect that his work would have a historical effect dwindled considerably. The rising tide of European fascism deprived Benjamin's study of its anticipated audience, just as it would soon deprive him of his life. As the parameters of historical possibility narrowed, the eschatological motifs in his thought took on increasing prominence. His ideas would be received, if at all, only by an unnamed future witness. Of course, this eschatological focus would culminate in the "Theses on the Philosophy of History," which, as a strategy of historical remembrance amid catastrophe, is intimately related to the concerns of the Arcades Project. ${ }^{73}$

In his notes to the Passagenwerk, Benjamin never made an effort to conceal the centrality of theological concerns. In his reflections on theory of knowledge, he observes: "My thought is related to theology as a blotter is to ink. It is totally absorbed by it. If it were up to the blotter, however, nothing of what has been written would remain"74-an indication of both the extraordinary power and the dangers of the theological understanding of history to which Benjamin had been so profoundly attracted since his youth. The centrality of theology also meant that the question of redemption was to him a foremost concern in his understanding of the past. 
Among the "elementary principles of historical materialism" he lists the following bold claim: "The object of history is that for which knowledge enacts its redemption [Rettung]. . . . The authentic conception of historical time is wholly based on the image of salvation [Erlösung]."75

In the "Theses" Benjamin would speak of a "secret agreement" that exists between "past generations and the present one." $\mathrm{He}$ emphasizes that "the past carries with it a temporal index by which it is referred to redemption." 76 This is the reason he insisted on the methodological primacy of remembrance, as opposed to a concept of "progress" that would be superficially future-oriented. $\mathrm{He}$ invested this faculty with profound theological powers. For only via remembrance could the "secret agreement" between generations-i.e., between the living and the departed-be redeemed. Through it alone could criticism reactivate that "temporal index of redemption" that lay dormant in the past. For similar reasons he would insist that socialism is "nourished by the image of enslaved ancestors rather than that of liberated grandchildren." 77

The version of historical materialism that Benjamin envisioned-one whose victory, according to the imagery of Thesis I, was contingent upon enlisting "the services of theology"-was, therefore, eschatological in the strong sense. The lines between the dawning of a classless society and the advent of the Messiah were blurred to the point where the claims of Marxism overlapped with those of the Last Judgment: the wicked would be duly punished and the righteous dead would be resurrected.

It is fair to conclude that when, in the course of his reflections on the philosophy of history, Benjamin invoked the coming of the messianic era ("every second of time [is] the strait gate through which the Messiah might enter"), ${ }^{78}$ he was not speaking metaphorically. In the notes to the Arcades Project he insists that the dialectical recuperation of cultural history must reach a point where "the entire past has been brought into the present in a historical apocatastasis"79_-that is, a messianic retrieval of everything and everyone. His intentions were not merely directed toward a revamped historical materialism, but toward a full-blown political messianism:

In the Jewish apocalyptic and Neoplatonic-Gnostic traditions, apocatastasis refers to the restoration of an original paradisiacal state brought about by the coming of the Messiah. With this restoration, things would resume 
their proper relations to each other, the displacements that characterized the "dream condition of the world" would be undone. The goal of Benjamin's "dialectics of cultural history" is thus the abolition of the prevailing context of expression in favor of the original context of Being. . . Thus Benjamin transfers the catastrophic and redemptive elements coexistent in the apocalyptic doctrine of apocatastasis into the secular realm of history. ${ }^{80}$

It was precisely this tendency to attribute eschatological, redemptory force to the powers of theory that would lead to misunderstandings in his dealings with the more empirically oriented Institute for Social Research. In a letter of the late 1930s, Horkheimer would attempt to temper Benjamin's inclination toward speculative grandiosity with the following hard-headed reminder: "Past injustice has occurred and is done with. The slain are really slain. . . If one takes the idea of open-endedness seriously, then one must believe in the Last Judgment. . . . the injustice, horror, and pain of the past are irreparable." To which Benjamin offers the following unrepentant response:

The corrective to this way of thinking lies in the conviction that history is not only a science but also a form of remembrance. What science has "established" can be modified by remembrance. Remembrance can make the open-ended (happiness) into something concluded and the concluded (suffering) into something openended. This is theology; however, in remembrance we have an experience that forbids us from conceiving history fundamentally atheologically, even though we would hardly be able to write it in theological concepts that are immediately theological. ${ }^{81}$

Benjamin's shift in the late 1930s toward an avowedly apocalyptical-messianic perspective is especially evident in his second draft of the Arcades Exposé, written in 1939. In the later version, the section on "Daguerre or the Panoramas" was deleted, leaving five instead of the six projected chapters. More importantly, though, he added a new introduction and conclusion, which in the estimation of the editors of Benjamin's works, "contain . . . perhaps Benjamin's most lucid remarks concerning the theoretical goals of the Passagenwerk." 82

Of greatest theological significance in the new version were Benjamin's meditations on a relatively obscure prison-writing by the professional revolutionary Auguste Blanqui. The text, titled L'éternité par les astres, became for him an intellectual discovery of the high- 
est order. He describes his momentous first encounter with it in a January 1939 letter to Horkheimer:

One must concede that on first glance the text seems inept and banal. Still, the awkward reflections of an autodidact contained in the first part are preparation for speculation about the universe that no one but this great revolutionary could provide. If hell is a theological object, then one could call such speculation theological. The view of the world that Blanqui outlines is infernal, insofar as he takes his data from the mechanistic natural science of bourgeois society; it is at the same time a complement to the society that Blanqui in the twilight of his life was forced to recognize as victorious over himself. What is so disturbing is that this sketch lacks all irony. It presents an image of unreserved submission [Verwerfung]. . . . Its theme, eternal recurrence, has the most remarkable connection to Nietzsche. ${ }^{83}$

What Benjamin found of great value in Blanqui's otherwise unexceptional treatise was his vision of contemporary society as characterized by an infernal-mythological compulsion-to-repeat-hence the affinities with Nietzsche's doctrine of eternal recurrence. This was of course a theme that stood in close proximity to one of the Arcades Project's main concerns: to portray the cultural superstructure of high capitalism as a type of modern mythology, thereby unmasking the secret affinities between modernity and prehistory.

Blanqui wrote this extremely dispirited text in 1872 while imprisoned in Fort du Taureau following the suppression of the Paris Commune. It is the testimony of a beaten man, one who has recently seen his most cherished hopes for humanity's future brutally crushed. Undoubtedly, Benjamin found himself attracted to Blanqui's cosmic pessimism for reasons that were as much biographical as theoretical: the sense of hopelessness that pervades Blanqui's text was one with which Benjamin identified profoundly.

The key passage in this fable of eternal recurrence reads as follows:

There is no progress. ... What we call progress is immured on each planet and vanishes with it. Everywhere and always, the same drama, the same decor, on the same narrow stage, a clamorous humanity, infatuated with its greatness, believing itself to be the entire universe and living in its immense prison, soon about to sink with the globe that has brought the burden of its pride into such a contemptuous state. The same monotony, 
the same immobilism on the other stars. The universe repeats itself endlessly and runs in place. Eternity plays imperturbably in the infinity of its representations. ${ }^{84}$

For Benjamin, Blanqui's vision represented a profound confirmation of the theory of history of the Arcades Project: a portrait of the phantasmagoria of modernity as governed by a hellish-mythological compulsion to repeat: "Blanqui's cosmic speculation teaches that humanity will be prey to the anxiety of myth for so long as the phantasmagoria has a place in it." 85 According to Benjamin, the failure of the nineteenth century-and, by implication, of the twentieth as well-was that, "The century did not know how to respond to the new technological innovations with a new social order." 86 That is, it allowed the potentialities embodied in the new forces of production to remain trapped in outmoded (capitalist) relations of production. The cultural expressions of this society were able to project a utopian future-albeit, in a distorted dream-form. In the Arcades Project, Benjamin sought, as it were, to capture the "rational kernel" of these utopian wish-images and dream-states. In his valorization of Blanqui's profound cosmological gloom, the signature interrelationship in his work between decline and salvationVerfall and Erlösung - is once again plainly manifest.

The attempt to bring a messianic theory of history to bear on the course of secular world history is fraught with danger. This is not the locus where Benjamin's actuality should be sought out today. Benjamin dwelled amid exceedingly dark times. He thought that an infusion of secular messianism would help historical materialism compensate for its intrinsic theoretical rigidity, as well as for the lack of imminent revolutionary possibility. To think about the prospects for social change in such terms today would be deceptive. Benjamin's boyhood friend Scholem, who went on to become the century's greatest authority on the tradition of Jewish Messianism, well understood the dangers inherent in conflating the secular and the messianic: "I think that the failure to distinguish between messianism and secular movements is apt to trip up movements of this sort. Such a mix-up becomes a destructive element. This misapplication of messianic phraseology injected a false note into the minds and self-image of the devotees of those secular movements." 87

Conversely, to reassert Benjamin's lifelong, frenetic quest for happiness and fulfillment within the parameters of a democratically 


\section{lii INTRODUCTION TO THE REVISED EDITION}

constituted society would be an achievement worth emulating. Until such a condition has been achieved, the actuality of his thought will remain compelling.

R. W.

July 15, 1993

Notes

1. This movement has been felicitously chronicled in Michael Löwy's recent work, Redemption and Utopia: Jewish Libertarian Thought in Central Europe (Stanford: Stanford University Press, 1992).

2. Zur Aktualität Walter Benjamins, S. Unseld, ed. (Frankfurt: Suhrkamp Verlag, 1972).

3. On the theme of redemptory political paradigms, see Ferenc Feher, "Redemptive and Democratic Paradigms in Radical Politics," Telos (Spring 1985) 63:147-56; Joel Whitebook, "The Politics of Redemption," Telos (Spring 1985) 63:156-68; Paul Breines, "Redeeming Redemption," Telos (Fall 1985) 65:152-58; Richard Wolin, "Against Adjustment," Telos (Fall 1985) 65:158-63; and Moishe Gonzales, "Theoretical Amnesia," Telos (Fall 1985) 65:163-70.

4. For two recent articulations of this position (which may be traced to John Locke's Letter Concerning Toleration), see John Rawls, "Justice as Fairness: Political not Metaphysical," Philosophy and Public Affairs (Summer 1985) 14:223-51; and Richard Rorty, Contingency, Irony, and Solidarity (Cambridge: Cambridge University Press, 1990).

5. Irving Wohlfarth, "Re-fusing Theology: Some First Responses to Walter Benjamin's Arcades Project," New German Critique (Fall 1986) 39:17.

6. Benjamin, Gesammelte Schriften V, p. 592. All subsequent references to this edition will cite the volume and page number only.

7. Benjamin, "One-Way Street," Illuminations, p. 84.

8. V, p. 168.

9. Benjamin, "Theses on the Philosophy of History," Illuminations, p. 258.

10. One of the best examples of this phenomenon is provided by postmodernist director Wim Wenders' 1988 film, "Wings of Desire" ("Himmel über Berlin"), which is loosely based on Benjamin's "Theses on the Philosophy of History." The angel of Wenders' film descends to survey contemporary Berlin and its luckless inhabitants. It is a desolate and hopeless cityscape: literally a hell on earth, which is intended as an allegory for the ruins of modernity. Yet, unlike Benjamin, in Wenders' film, there is no allusion to that "strait gate through which the Messiah might enter." As a result, the film remains a testament to decline purely and 
simply. It is in no way an allegory of redemption, as is the case with Benjamin's "angel of history."

11. Benjamin, "Theses on the Philosophy of History," p. 263.

12. Susan Buck-Morss has commented on the relationship between Benjamin and postmodernism in The Dialectics of Seeing (Cambridge: MIT Press, 1989). According to Buck-Morss, the attempt to view him as "the precursor of such recent, postsubjective currents of thought as deconstruction and postmodernism" must fail, insofar as these schools are "characterized not infrequently by an anthropological nihilism which [Benjamin] criticized vehemently" (p. 222). Toward the end of her impressive study, she makes the following (somewhat risky) claim: "Whereas modernism in philosophical terms is wedded to the Enlightenment dream of a substantively rational society, postmodernism takes its philosophical lead from Nietzsche, Baudelaire, and Blanqui. If the terms are defined this way, Benjamin must be counted as a modernist" (p. 447, note 35).

For an early debate on Benjamin's relation to deconstruction, see Irving Wohlfarth's response to Carol Jacobs, The Dissimulating Harmony (Baltimore: Johns Hopkins, 1978), "Walter Benjamin's 'Image of Interpretation," New German Critique (Spring 1979) 17:70-98.

13. Benjamin, "Theses on the Philosophy of History," p. 257.

14. For example, see Michael Taussig's attempt to generalize Benjamin's conception of the "state of emergency" ("Ausnahmezustand"-in truth, "state of exception") in The Nervous System (New York: Routledge, 1992); especially, chapter 2, "Terror as Usual: Walter Benjamin's Theory of History as State of Siege." Taussig speaks of "the violence in our own immediate life-worlds, in our universities, workplaces, streets, shopping malls, and even families, where, like business, it's terror as usual," and of "the irregular rhythm of numbing and shock that constitutes the apparent normality of the abnormal created by the state of emergency" (pp. 12-13).

15. For an account of the origins of the term posthistoire, see Lutz Niethammer, Posthistoire: ist die Geschichte zu Ende (Reinbeck bei Hamburg: Rowohlt, 1989).

16. V, 570-71.

17. Friedrich Nietzsche, The Will to Power, trans. W. Kaufmann and R. J. Hollingdale (New York: Vintage, 1967), p. 9.

18. On this theme, see the important study by Stephen Aschheim, The Nietzsche Reception in Germany, 1890-1990 (Berkeley: University of California, 1992).

19. Scholem, On Jews and Judaism in Crisis, p. 194-95.

20. See, for example, his letter of July 7, 1935 where he speaks of the Arcades Project as "designed to become the pendant to my study of the seventeenth century which appeared in Germany under the title Origin of German Tragic Drama" (V, p. 1124).

21. For Nietzsche's distinction between active and passive nihilism, see The Will to Power, p. 17.

22. Benjamin, "Surrealism: The Last Snapshot of the European Intelligentsia," in Reflections, Essays, Aphorisms and Autobiographical Writings, P. Demetz, ed. 
(New York: Harcourt Brace, 1978), p. 187. Or, as he expresses this thought elsewhere: "the traditional image of humanity-ceremonious, noble, decked out with all the sacrificial offerings of the past" ("Erfahrung und Armut," II, p. 216).

23. Benjamin, "Surrealism," pp. 181-82; emphasis added.

24. Benjamin, "The Destructive Character," in Reflections, p. 301.

25. Benjamin, "Karl Kraus," in Reflections, p. 272.

26. Benjamin, Briefe, p. 425. See also the discussion of these themes on pp. $117 \mathrm{ff}$, below.

27. On this theme, see Karl-Heinz Bohrer, Ästhetik des Schreckens (Munich: Hanser, 1978), where the work of Benjamin and Jünger is compared extensively. Of course, Benjamin recognized this problem in his critique of Jünger (III, p. 240). See also the concluding sentences of his "Work of Art Essay," where Benjamin warns that in its glorification of war, fascism celebrates "destruction as an aesthetic pleasure of the first order."

For a good discussion of the dangers of Benjamin's nihilist outlook, see John McCole, Walter Benjamin and the Antinomies of Tradition (Ithaca: Cornell University Press, 1993), pp. 165ff. McCole correctly identifies a "liquidationist" component as prominent in all phases of Benjamin's thought. It can be traced back as early as his involvement with the Youth Movement in the 1910s, where his nihilistic attitudes toward the present age are prominent. But they are also evident in his later work: for example, his endorsement of the "decline of the aura" in the "Work of Art" essay; a thesis which relates destructively rather than conservatively to the dissolution of traditional culture and its semantic potentials.

28. On this question, see Fritz Ringer, The Decline of the German Mandarins; and Fritz Stern, The Failure of Illiberalism (New York: Knopf, 1922).

29. The term a "more real humanism" appears in his essay on Karl Kraus; see Reflections, p. 272. For the characterization of Klee's Angelus Novus, see p. 273.

30. Benjamin, "Surrealism," pp. 190, 192; emphasis added. For one of the most successful explorations of Benjamin's understanding of what surrealism might contribute to the Marxist tradition, see Margaret Cohen, Profane Illumination: Walter Benjamin and the Paris of Surrealist Revolution (Berkeley: University of California Press, 1993). See also, Josef Fürnkas, Surrealismus als Erkenntnis (Stuttgart: Metzler, 1988). Fürnkas' work is more specifically concerned with an analysis of Benjamin's short prose works.

Adorno was highly critical of Benjamin's employment of anthropological materialism. He saw this concept as essentially undialectical. Because of its surrealistinspired infatuation with the idea of "brdily collective exaltation," he viewed it as an expression of immediacy in the Hegelian sense; even worse, it expressed an inclination toward fetishizing the reified immediacy of given social relations. On this point see Adorno's letter to Benjamin of September 6, 1936, VII, p. 864, where he accuses the latter of flirting with "an undialectical ontologization of the body." In this sense, Adorno's critique of anthropological materialism was very much akin to his critique of surrealism in the 1950s. See Adorno, "Looking Back on Surrealism," in Notes to Literature, trans. S. W. Nicholsen (New York: Columbia University Press, 1991), pp. 86-90. 
31. Scholem, "Walter Benjamin," Neue Rundschau (1) (1965) 76:19; reprinted in On Jews and Judaism in Crisis, p. 195.

32. Habermas, "Consciousness-Raising or Rescuing Critique," in On Walter Benjamin: Critical Essays and Recollections, Gary Smith, ed. (Cambridge: MIT Press, 1988), pp. 113, 124.

33. See Georg Stauth and Bryan S. Turner, "Ludwig Klages and the Origins of Critical Theory," Theory, Culture and Society (1992) 9:45-63. The authors claim that "The Frankfurt School was closer to the tradition of Nietzsche and Lebensphilosophie in their cultural critique than to Marxism" (p. 45). This claim is certainly worth exploring. Yet, the authors fail to address the question of how, if substantiated, it would affect the contemporary relevance of critical theory. Moreover, in dealing with the Frankfurt School as a whole, they fail to take into account the fact that a similar claim could in no way be made for the critical theory of the 1930 s, whose production revolved around the concept of "interdisciplinary materialism." See also the predominantly biographical account in Werner Fuld, "Walter Benjamins Beziehung zu Ludwig Klages," Akzente (1981) 28:274-87.

34. Also see Axel Honneth's exploration of this problem in "'L'Esprit et son object': Parentés anthropologiques entre la 'Dialectique de la Raison' et la critique de la civilisation dans la philosophie de la vie," in Weimar ou l'explosion de la modernité, G. Raulet, ed. (Paris: Editions Anthropos, 1984), pp. 97-111. Honneth argues that "in light of the contemporary critique of reason it seems that Dialectic of Enlightenment is anchored more than one would have thought in the tradition of a critique of civilization inspired by philosophy of life." I agree with Honneth's characterization.

35. Wolin, "Critical Theory: From Interdisciplinary Materialism to Philosophy of History," in Wolin, The Terms of Cultural Criticism: The Frankfurt School, Existentialism, Poststructuralism (New York: Columbia University Press, 1992).

36. Benjamin's letter to Schmitt may be found in I, 3, p. 887. Some have pointed out that the allusion to the Ausnahmezustand-the "state of exception"in the "Theses" derives from Schmitt. But given the precarious nature of European politics in 1940 , it would seem that the concept had an immediate historical point of reference.

37. The 1923 letter was partially reprinted in TEXT + KRITIK (1971), 31/32:24. See Benjamin's positive evaluation of Klages' 1922 text in III, p. 44.

38. Benjamin, "Johann Jakob Bachofen," in II, pp. 229-31. The Bachofen essay was unpublished during Benjamin's lifetime and written in French (at the behest of the Nouvelle Revue Française, which eventually rejected it).

39. Benjamin, letter to Adorno, January 7, 1935, Briefe, pp. 638ff.

40. Adorno, letter to Benjamin, December 12, 1934, cited in II, p. 966.

41. See especially Negative Dialectics, pp. 162-64. As Rolf Wiggershaus has remarked: "A major confrontation with Klages and his theory of the image appeared as an urgent task for both [Benjamin] and Adorno in the 1930s in order to clarify their own standpoint and the theory of dialectical images." Wiggershaus, Die Frankfurter Schule: Geschichte, Theoretische Entwicklung, Politische Bedeutung (Munich: Hanser, 1986). English translation to appear with MIT Press. 
42. Reported by Wiggershaus, Die Frankfurter Schule, p. 224.

43. Klages, "Vom Traumbewusstein," in Sämtliche Werke 3 (Bonn: Bouvier, 1974), p. 162.

44. Honneth, "Erschliessung der Vergangenheit," Internationale Zeitschrift für Philosophie 1 (1993). Honneth's analysis contains an interesting account of Jünger's diary, Das Abenteuerliche Herz (1929), as it relates to Benjaminian themes. See the reference to Bohrer in note 27.

45. See Bruce Detwiler, Nietzsche's Aristocratic Radicalism (Chicago: University of Chicago Press, 1990).

46. Jünger, "Das Abenteuerliche Herz," in Sämtliche Werke, vol. 9 (Stuttgart: Klett-Cotta, 1978-1983), p. 259.

47. III, pp. $238-50$.

48. Benjamin, Illuminations, pp. 156-57, 202.

49. Briefe, p. 409.

50. Ibid., p. 515. For a brief discussion of Klages' relation to fascism (although he never joined the movement per se, many of his theories were taken up by Nazi ideologues such as Alfred Rosenberg), see Stauth and Turner, "Ludwig Klages and the Origins of Critical Theory," pp. 57-59.

51. V, p. 1161. See also the exchanges between Adorno and Benjamin on this subject in V, pp. $1160-61$. Since the publication of volume $V$, new correspondence between Adorno and Horkheimer concerning Benjamin's relation to Jung and Klages has come to light. See VII, pp. 866-68.

52. For a discussion of the relationship between Lebensphilosophie and the fascist ideology, see Herbert Marcuse, "The Struggle Against Liberalism in the Totalitarian Conception of the State," in Negations; and Lukács, The Destruction of Reason (London: Merlin Press, 1980).

53. Adorno, letter to Benjamin of August 2, 1935, in Aesthetics and Politics, p. 113. See the discussion of the Adorno-Benjamin debate, pp. 173-83.

54. For a good discussion of Benjamin's relation to Kommerell, see McCole, Walter Benjamin and the Antinomies of Tradition, p. 176-78.

55. See the remarks from the Arcades Project, V, pp. 493-94. Benjamin begins with a reference to "the forms of appearance of the dream-collective of the nineteenth century" and continues:

The 'critique' of the nineteenth century must begin here. Not as a critique of its mechanism and machinism, but instead of its narcotic historicism, of its mania for masks [Maskensucht], in which nevertheless is hidden a signal of true historical existence which the surrealists were the first to perceive. The project that follows consists of an attempt to decipher that signal. And the revolutionary, materialist basis of surrealism is a sufficient guarantee that the economic basis of the nineteenth century has reached its highest expression in the signal of true historical existence-which is what concerns us here.

56. Kurt Sontheimer, Antidemokratisches Denken in der Weimarer Republik (Munich: Nymphenburger, 1962), p. 51.

57. The title of a book written by the national revolutionary thinker Hans Freyer (Jena, 1931). 
58. Habermas, "Consciousness-Raising or Redemptive Critique," p. 113.

59. V, 591-92.

60. See Michel Espagne and Michael Werner, "Les manuscrits parisiens de Walter Benjamin et le Passagen-Werk," Walter Benjamin et Paris, H. Wismann, ed. (Paris: Cerf, 1986); and Espagne and Werner, "Vom Passagen-Projekt zum 'Baudelaire': Neue Handschriften zum Spätwerk Walter Benjamins," Deutsche Vierteljahrsschrift für Literaturwissenschaft und Geistesgeschichte (December 1984) 68(4):593657. In the latter work, the authors appear to modify some of the more farreaching conclusions reached in "Les manuscrits parisiens."

61. Benjamin, Nachträge (Gesammelte Schriften VII), pp. 870-72. See also, Buck-Morss, The Dialectics of Seeing (Cambridge: MIT Press, 1989), pp. 206-208.

62. Espagne and Werner, "Les manuscrits parisiens de Walter Benjamin et le Passagen-Werk," p. 852.

63. Buck-Morss, The Dialectics of Seeing, p. 208:

Given that the planned Baudelaire book was first conceived as a chapter of the larger work, would it not be reasonable to assume that all of the "chapters," so condensed and abbreviated in both expose descriptions would ultimately have been extended to the point where each could, and indeed should, stand on its own? . . The possibility that, in order to give himself space to develop the historical significance of what was now over a decade of research, Benjamin would have dissolved the "Passages" into a series of works, all of which were within the same theoretical armature, does not indicate a "failed" Passagen-Werk, but, on the contrary, one that had succeeded only too well [the allusion to "a 'failed' Passagen-Werk" is directed critically to the Espagne-Werner interpretation].

64. V, p. 1054.

65. V, p. 574. See also V, p. 575 :

A central Problem of historical materialism that finally must be considered: whether the Marxist understanding of history must be unconditionally purchased at the expense of its [history's] visuality [Anschaulichkeit]? Or: how would it be possible to link heightened visuality with the carrying out of the Marxist method? The first step of this way will be to incorporate the principle of montage in history. Thus, to erect the largest constructions from the smallest, most sharply and keenly tailored elements [Bausteine]. Thereby, to discover the crystal of the total event in the analysis of small individual moments.

66. Tiedemann expresses doubts about Adorno's thesis in his introduction to the Passagenwerk, V, p. 13. Benjamin's description of the Baudelaire study as a "miniature model" of the Arcades Project may be found in V, p. 1164.

67. Adorno, letter to Scholem of May 9, 1949, in V, pp. 1072-73.

68. Benjamin, letter to Gretel Karplus (Adorno) of August 16, 1935, in V, p. 1139.

69. V, p. 595.

70. V, pp. 583,580 .

71. V, pp. 495-96.

72. V, pp. $46-47$.

73. From a philological standpoint, moreover, it is worth pointing out that 


\section{lviii INTRODUCTION TO THE REVISED EDITION}

there is considerable overlap between the notes to the "Theses" and those to section $\mathrm{N}$ of the Arcades Project on theory of knowledge and theory of progress.

74. V, p. 588.

75. V, pp. 595,600 .

76. Benjamin, Illuminations, p. 254.

77. Ibid., p. 260.

78. Ibid., p. 264.

79. V, p. 573.

80. Bernd Witte, "Paris-Berlin-Paris: Personal, Literary, and Social Experience in Walter Benjamin's Late Works," New German Critique (Fall 1986) 39:57.

81. V, p. 589.

82. V, p. 1255. They go on to add that "the modifications vis-à-vis the older text [i.e., the 1935 version] are especially instructive concerning the development of Benjamin's theoretical views over the course of the four years that spanned the composition of the two Exposés."

83. V, p. 169. A slightly different account of the same reflections may be found in Benjamin, Briefe, pp. 741-42. A number of these reflections found their way into the second draft of the Arcades Exposé, V, p. 75.

84. V, p. 76.

85. V, p. 61. For an interesting discussion of Blanqui's importance for Benjamin, see Miguel Abensour, "Walter Benjamin entre mélancholie et révolution," in Walter Benjamin et Paris, H. Wismann, ed. (Paris: Le Cerf, 1986), pp. 219-49.

86. V, p. 61.

87. Scholem, On Jeus and Judaism in Crisis, p. 26. 